\title{
Pengembangan buku ajar sensor tranduser berbasis problem solving untuk mahasiswa S1 Pendidikan Teknik Elektro Fakultas Teknik Universitas Negeri Malang
}

\author{
Mokhammad Nasrulloh', Siti Sendari², I Made Wirawan ${ }^{3}$ \\ 1. Universitas Negeri Malang, Indonesia | n4srulloh.mukhammad@gmail.com \\ 2. Universitas Negeri Malang, Indonesia | siti.sendari.ft@um.ac.id \\ 3. Universitas Negeri Malang, Indonesia | made.wirawan.ft@um.ac.id
}

\begin{abstract}
Abstrak
Proses pembelajaran yang dilakukan pada matakuliah Sensor dan Tranduser mengalami kendala dalam materi yang akan diajarakan dimana referensi sumber belajar masih kurang. Adanya bahan ajar yang kurang memadai mengakibatkan mahasiswa mengalami kesulitan dalam menangkap materi yang diajarkan. Salah satu cara untuk mengatasi permasalahan tersebut adalah dengan mengembangkan buku ajar dimana digunakan sebagai rujukan dalam proses pembelajaran maupun sebagai sumber belajar mahasiswa secara mandiri. Penelitian ini menggunakan model Borg dan Gall yang telah disesuaikan. Tahapannya yaitu (research and information collecting, planning, develop preliminary from of product, preliminary test, main product revition, main field testing, and operational product revition). Kelayakan pengembangan buku ajar dapat dilihat dari hasil validasi dan uji coba dengan mengunakan penyebaran angket. Hasil penyebaran angket yang telah dilakukan pada buku ajar dinyatakan valid, sehingga layak digunakan sebagai sumber rujukan pembelajaran Manajemen Energi. Hal ini didukung melalui hasil persentase validasi oleh ketiga validator dengan rata-rata hasil validator sebesar $89,78 \%$, hasil validasi uji coba kelompok kecil sebesar $88,29 \%$, dan hasil validasi uji coba kelompok besar yaitu $90,56 \%$. Dari persentase tersebut dapat dikatakan bahwa produk buku ajar bisa digunakan atau layak jika digunakan sebagai reverensi belajar atau sebagai bahan ajar Sensor dan Tranduser.
\end{abstract}

Kata Kunci

Buku ajar, sensor, tranduser, problem solving 


\section{TEKNO Jurnal Teknologi Elektro dan Kejuruan}

http://journal2.um.ac.id/index.php/tekno | ISSN 1693-8739 / 2686-4657

\section{Pendahuluan}

Mutu proses belajar mengajar dapat diperoleh sebagai aktivitas mengajar yang dilakukan oleh pendidik dan aktivitas mengajar yang dilakukan oleh peserta didik di kelas, laboratorium, dan ruang belajar lainnya (Hadis dan Nurhayati, 2012). Proses belajar mengajar yang bermutu adalah suatu kegiatan yang dilakukan di kelas yang mencakup beberapa unsur yaitu pengembangan sikap positif terhadap kerja (Putri dan Imaniyati, 2017), belajar, serta pemecahan masalah (Lestari dan Sofyan, 2014).

Proses belajar mengajar yang baik apabila terdapat bahan ajar yang mendukung untuk membantu meningkatkan kualitas belajar mengajar (Setiawan dkk, 2016; Ervina dkk, 2017; Lestari dan Hartati, 2017). Bahan ajar merupakan segala bahan (baik informasi, alat maupun teks) yang disusun secara sistematis, yang menampilkan secara keseluruhan kompetensi yang akan dikuasai peserta didik dan digunakan dalam proses pembelajaran dengan tujuan perencanaan dan penelaahan media pembelajaran (Prastowo, 2012). Dalam penelitian ini, kurikulum yang digunakan mengacu pada katalog Jurusan Teknik Elektro Universitas Negeri Malang pada matakuliah Sensor dan Tranduser.

Kurikulum yang terdapat dalam matakuliah Sensor dan Tranduser terdiri dari: mengidentifikasi parameter dan karakteristik bermacam-macam sensor dan transduser serta dapat diterapkan pada sistem instrumentasi dan kontrol dengan deskripsi kompetensi antara lain (1) parameter dan karakteristik sensor dan tranduser meliputi a) sensor temperatur, b) sensor tekanan/gaya, c) sensor aliran, d) sensor cahaya, e) sensor ultrasonik, f) sensor magnetik, dan g) sensor displacement. (2) pengkondisi sinyal dan filter, dan (3 sensor dan tranduser dalam sistem instrumentasi dan kontrol.

Berdasarkan hasil wawancara yang dilakukan dengan mahasiswa yang telah menempuh matakuliah sensor dan tranduser diperoleh informasi bahwa mahasiswa belum memiliki pengetahuan dasar belajar sensor dan tranduser mengenai dasar-dasar sensor, prinsip kerja dari berbagai sensor yang akan dipelajari, dan menerapkan sensor dan tranduser dalam sistem kendali sesuai dengan standar kompetensi. Sehingga mahasiswa mengalami kesulitan dalam mempelajari matakuliah sensor dan tranduser.

Berdasarkan permasalahan tersebut peneliti memilih model pembelajaran problem solving. Model pembelajaran problem solving dapat membuat mahasiswa lebih aktif dalam kelas, karena di dalam setiap pembelajaran mahasiswa dituntut untuk menggali informasi terkait masalah yang sedang di hadapi (Sunarti dan Rohmawati, 2014). Penggunaan model pembelajaran problem solving diindikasikan dapat membuat mahasiswa aktif dalam kelas (Widiani, 2016), karena pada langkah-langkah model pembelajaran problem solving mahasiswa dibimbing untuk menghadapi masalah di dalam setiap pembelajaran, adapun langkahlangkahya antara lain: (1) mahasiswa menemukan masalah yang jelas untuk dipecahkan, (2) mahasiswa dituntut untuk menggali informasi terkait masalah yang dihadapi, (3) mahasiswa menetapkan jawaban sementara yang didasarkan pada data yang telah diperoleh, (4) mahasiswa menguji kebenaran jawaban sementara, dan (5) mahasiswa menyimpulkan jawaban 


\section{TEKNO Jurnal Teknologi Elektro dan Kejuruan}

http://journal2.um.ac.id/index.php/tekno | ISSN 1693-8739 / 2686-4657

dari permasalahan yang dihadapi. Penerapan memilih model pembelajaran problem solving pada bahan ajar dapat digunakan sebagai salah cara agar mahasiswa dapat menyerap informasi yang di sampaikan oleh pendidik dalam beberapa deskripsi kompetensi yaitu 1) menelaah karakteristik dan parameter sensor sensor temperatur, sensor tekanan, sensor jarak, dan sensor gas 2) merancang pengkondisi sinyal dan filter, serta 3) menerapkannya dalam sistem kendali. Berdasarkan permasalahan tersebut, pengembang membuat media berupa buku ajar cetak berbasis pemecahan masalah sebagai solusi mengatasi permasalahan tersebut.

Berdasarkan hasil observasi yang telah dilakukan di dapatkan hasil bahwa bahan ajar yang digunakan di Jurusan Teknik Elektro Universitas Negeri Malang adalah jobsheet praktikum dan handout, sedangkan buku ajar sensor dan tranduser belum ada. Isi jobsheet praktikum dan handout yang telah dikembangkan meliputi: (1) Handout Sensor yang dikembangkan oleh Rusdiyanto (2015) meliputi sensor cahaya (LDR dan Photodioda), sensor temperatur meliputi (NTC, LM35, dan Termokopel), sensor tekanan loadcell, dan sensor proximity meliputi proximity kapasitif dan proximity induktif; (2) Jobsheet Praktikum Sensor dan Tranduser yang di kembangkan oleh Putra (2017) meliputi sensor temperatur, sensor cahaya, sensor kelembaban, sensor gas, sensor tekanan strain gauge, dan sensor ultrasonik.

Kekurangan dari kedua bahan ajar tersebut yaitu isi bahan ajar belum mencakup deskripsi kompetensi yang ada dalam katalog S1 Pendidikan Teknik Elektro 2018. Kondisi bahan ajar yang ada sekarang di jurusan teknik elektro adalah handout sensor dan tranduser dan jobsheet sensor dan tranduser, oleh karena itu dibutuhkan bahan ajar yang sesuai dengan kompetensi yang hendak dicapai pada mata kuliah sensor dan tranduser sesuai dengan katalog S1 Pendidikan Teknik Elektro 2018 sehinga dapat melengkapi bahan ajar yang telah dikembangkan.

Bahan ajar yang akan di kembangkan berupa buku ajar dengan 8 topik diantaranya: (a) aktuator yang terdiri dari solenoid, motor DC, motor servo, dan motor stepper, (b) sensor suhu dan kelembaban yang terdiri dari sensor PTC dan NTC, LM35, HS-15P dan HS-1101, (c) sensor cahaya yang terdiri dari sensor LDR (Light Dependent Resistor), photodioda, photo transistor, (d) sensor mekanik yang terdiri dari sensor rotary encoder, (e) sensor beban yang terdiri dari sensor strain gauge, load cell, dan piezoelektrik, (f) sensor gas yang terdiri dari sensor TGS 2610, AF30, AF63, MQ-2, dan MQ-7, (g) sensor Proximity yang terdiri dari sensor Proximity Induktif, dan Proximity Kapasitif, (h) sensor jarak yang terdiri dari sensor ultrasonik dan PIR.

\section{Metode}

Pengembangan buku ajar sensor tranduser berbasis problem solving menggunakan model pengembangan Borg dan Gall. Model pengembangan Borg dan Gall dipilih karena tahaptahapnya sesuai dengan penelitian yang akan digunakan untuk menguji validitas sebuah produk berupa buku ajar cetak. Pada penelitian menggunakan model pengembangan Borg dan Gall 


\section{TEKNO Jumal Teknologi Eektro dan Kejuruon}

http://journal2.um.ac.id/index.php/tekno | ISSN 1693-8739 / 2686-4657

tidak sampai melaksanakan 3 tahap terakhir dikarenakan beberapa pertimbangan. Tahap yang tidak dilaksanakan yaitu: operational field testing, final product revision, dan dissemination and implementation.

Tahap operational field testing dan final product revision tidak dilaksanakan karena beberapa alasan, diataranya: (1) merujuk pada pernyataan Borg dan Gall dalam Sugiyono (2014), bahwa pada tahap main field testing tercapainya tujuan pelaksanaan pengembangan sudah dapat diketahui, (2) keterbatasan akan pertimbangan waktu untuk melakukan uji coba penelitian. Sedangkan pada tahap dissemination and implementation tidak dilaksanakan karena produk berupa buku ajar tidak diterbitkan secara luas melainkan hanya di Jurusan Teknik Elektro Universitas Negeri Malang. Model pengembangan Borg dan Gall yang telah disesuaikan dengan kebutuhan dapat disajikan pada Gambar 1.

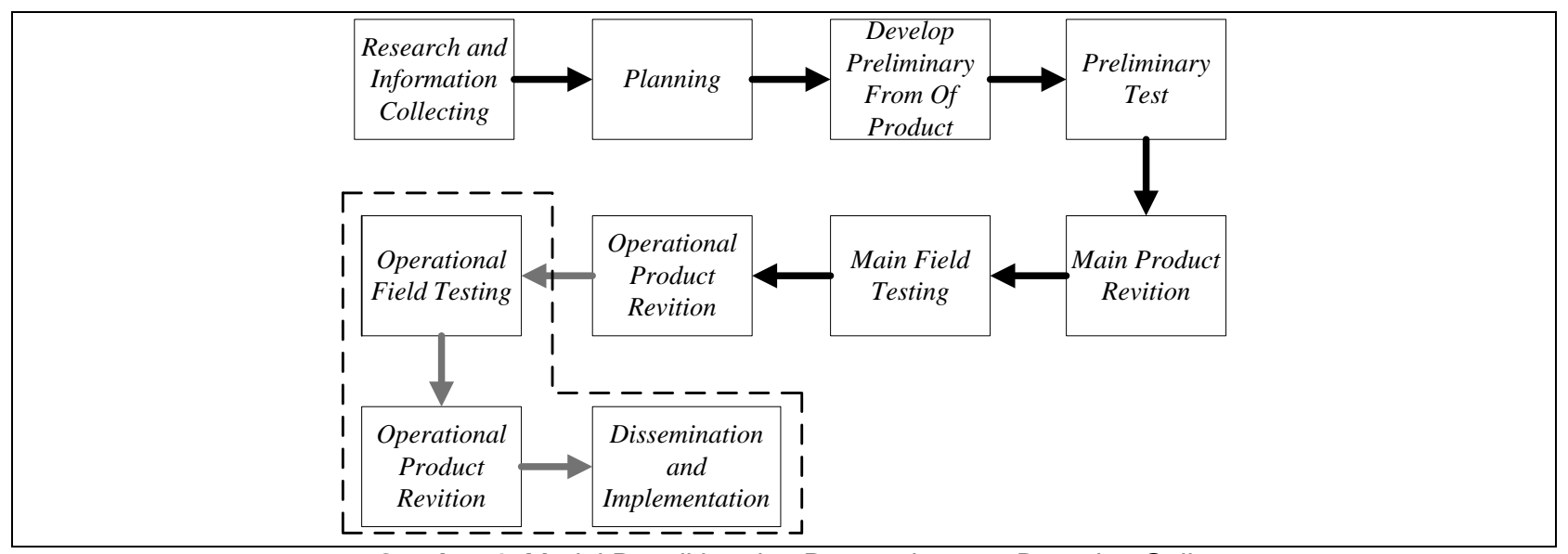

Gambar 1. Model Penelitian dan Pengembangan Borg dan Gall

Prosedur pengembangan ini menjelaskan tentang langkah-langkah yang digunakan dalam membuat Buku Ajar Sensor Tranduser berbsis problem solving. Berikut ini merupakan penjabaran penelitian dan pengembangan yang akan dilakukan:

1) Research and Information Collecting

Tahap ini merupakan tahap dimana mahasiswa menentukan dan mengidentifikasi masalah yang akan diselesaikan, maka dari itu diperlukan beberapa tahap sebagai berikut:

a) Pemilihan Materi

Sensor tranduser merupakan matakuliah wajib yang harus ditempuh dalam perkuliahan S1 Pendidikan Teknik Elektro di Universitas Negeri Malang. Berdasarkan observasi yang telah dilakukan di lab pembelajaran, bahan ajar sensor tranduser sebenarnya sudah ada antara lain Rusdiyanto (2015) dan Putra (2017), tetapi bahan ajar tersebut belum mencakup semua kompetensi yang ada di katalog S1 Pendidikan Teknik Elektro di Universitas Negeri Malang. 


\section{TEKNO Jumal Teknologi Elekro dan Kejurron}

http://journal2.um.ac.id/index.php/tekno | ISSN 1693-8739 / 2686-4657

b) Analisis Kebutuhan

Langkah pertama meliputi analisis kebutuhan pada katalog S1 Pendidikan Teknik Elektro 2018 matakuliah sensor dan tranduser dan modul dari penelitian sebelumnya serta studi pustaka yang mendukung. Pada katalog S1 Pendidikan Teknik Elektro 2018 matakuliah sensor dan tranduser belum adanya aktuator didalam deskripsi kompetensi, sebab aktuator juga termasuk ke dalam salah satu jenis tranduser. Materi aktuator perlu ditambahkan karena pada matakuliah lainnya seperti mikrokontroler, workshop PLC dan pneumatik, dan robotik terdapat aktuator didalamnya. Oleh karena itu materi aktuator perlu dipahami terlebih dahulu agar di matakuliah berikutnya mahasiswa sudah mengerti dan bisa mengerjakan tugas yang berkaitan dengan aktuator.

2) Planning

Berdasarkan katalog dan modul dari penelitian sebelumnya belum adanya aktuator dan kelengkapan materi pada modul sensor dan tranduser dan belum memenuhi deskripsi kompetensi yang disajikan. Hal-hal yang akan dilakukan peneliti dalam perencanaan pengembangan adalah mulai dari mencari berbagai referensi buku yang sesuai, memahami dengan seksama problematika yang dialami oleh mahasiswa ketika pembelajaran, membuat bahan ajar berbasis problem solving, memilih desain yang tepat, memilih layout yang sesuai dengan tema dan karakteristik mahasiswa S1 Pendidikan Teknik Elektro di Universitas Negeri Malang. Peta konsep dari katalog sensor dan tranduser dapat digambarkan pada Gambar 2.

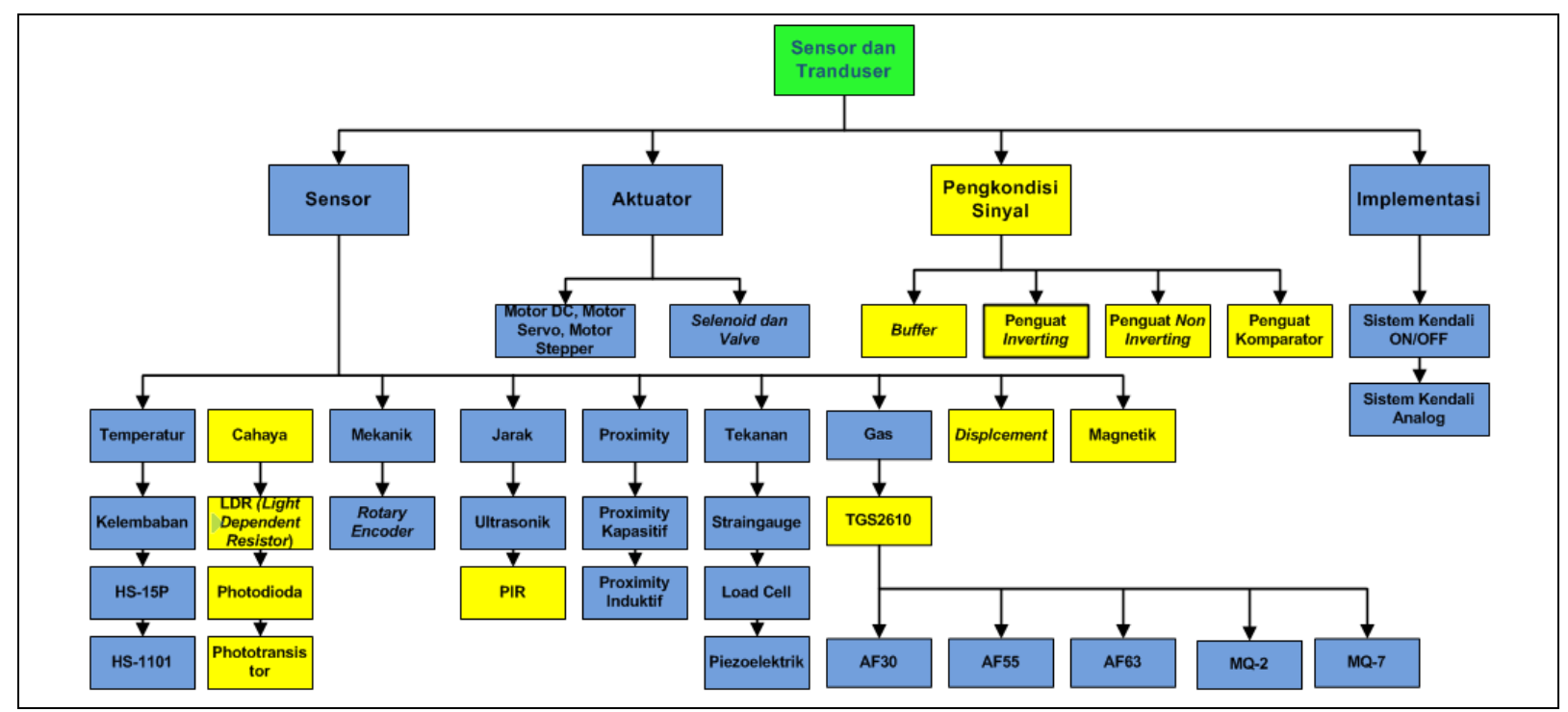

Gambar 2. Peta Konsep Buku Ajar Sensor dan Tranduser

TEKNO Vol. 29 Issue 2, p116-128 | Jurusan Teknik Elektro, Universitas Negeri Malang, Indonesia | September 2019 M. Nasrulloh, S. Sendari, I M. Wirawan | Pengembangan Buku Ajar Sensor Tranduser berbasis Problem Solving untuk... 


\section{TEKNO Jumal Teknologi Eektro dan Kejurvon}

http://journal2.um.ac.id/index.php/tekno | ISSN 1693-8739 / 2686-4657

Berdasarkan peta konsep pada Gambar 2, dapat disimpulkan bahwa materi yang akan dijadikan buku ajar sensor dan tranduser berbasis problem solving telah memenuhi kompetensi yang ada di Jurusan Teknik Elektro Universitas Negeri Malang, sehingga direncanakan katalog yang disajikan pada Gambar 3.

\begin{tabular}{|c|c|}
\hline & 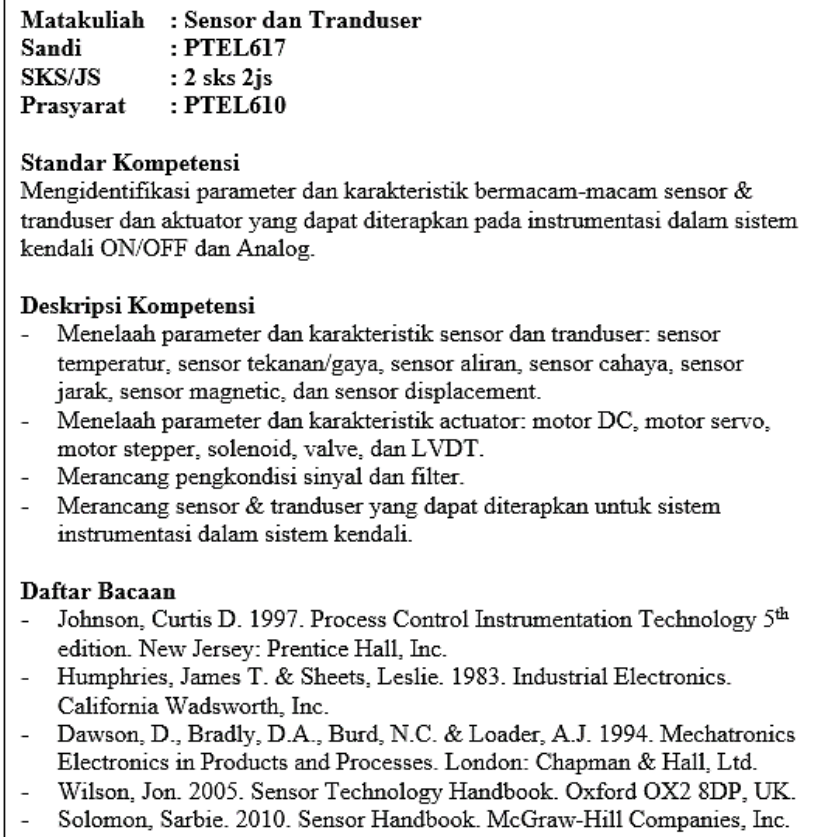 \\
\hline
\end{tabular}

Gambar 3. Katalog Matakuliah Sensor dan Tranduser

3) Develop Preliminary Form of Product

Pengembangan produk ini menjelaskan tentang desain produk yang akan dikembangkan dalam membuat buku ajar sensor tranduser berbasis problem solving. Berdasarkan observasi yang telah dilakukan di Lab. Pembelajaran untuk pengembangan buku ajar sensor tranduser berbasis problem solving pada matakuliah sensor dan tranduser sudah ada tetapi belum memenuhi kompetensi yang disajikan pada katalog sensor dan tranduser S1 Pendidikan Teknik Elektro 2018. Pada penelitian sebelumnya yang dikembangkan oleh Rudiyanto (2014) mengembangkan Handout Sensor dan Putra (2017) mengembangkan Modul Jobsheet Praktikum yang berisi beberapa sensor dan aplikasinya.

Pada pengembangan kali ini peneliti ingin melengkapi materi ajar sensor tranduser berdasarkan peta konsep pada Gambar 2. Materi yang sudah dikembangkan oleh peneliti terdahulu diadopsi juga pada penelitian ini tetapi konten tetap sama, supaya materi sensor dan tranduser dalam satu semester dapat dijadikan satu sehingga materi tidak terpisah- 


\section{TEKNO Jumal Teknologi Eektro dan Kejuruon}

http://journal2.um.ac.id/index.php/tekno | ISSN 1693-8739 / 2686-4657

pisah dan menjadi satu-kesatuan. Materi yang dikembangkan dan belum dikembangkan dapat ditunjukkan pada Tabel 1 dan Tabel 2.

Tabel 1. Materi Sensor yang akan Dikembangkan

\begin{tabular}{ll}
\hline \multicolumn{1}{c}{ Materi Ajar } & \multicolumn{1}{c}{ Materi yang sudah Dikembangkan } \\
\hline Sensor Suhu & Sensor PTC dan NTC \\
Sensor Cahaya & Sensor LDR dan Photodioda \\
Sensor Beban & Sensor Strain gauge dan Load cell \\
Sensor Proximity & Sensor Proximity Induktif dan Proximity Kapasitif \\
Sensor Gas & Sensor Gas TGS2610 \\
Sensor Jarak & Sensor Ultrasonik \\
Materi Ajar & Materi yang akan dikembangkan \\
Sensor Kelembaban & Sensor HS-15P dan HS-1101 \\
Sensor Cahaya & Sensor photo transistor \\
Sensor Mekanik & Sensor Rotary Encoder \\
Sensor Beban & Sensor piezoelektrik \\
Sensor Gas & Sensor AF30, AF63, MQ-2, dan MQ-7 \\
Sensor Jarak & Sensor PIR \\
Aktuator & Motor DC, motor servo, motor stepper, dan solenoid \\
Implementasi & Sistem kendali ON/OFF dan Analog \\
\hline
\end{tabular}

Tabel 2. Materi Sensor yang telah Dikembangkan

\begin{tabular}{ll}
\hline \multicolumn{2}{c}{ Rusdiyanto (2015) Handout Sensor dan Tranduser } \\
\hline Materi Ajar & \multicolumn{1}{c}{ Materi yang sudah Dikembangkan } \\
\hline Sensor Cahaya & $\begin{array}{l}\text { Sensor LDR (Light Dependent Resistor) dan } \\
\text { Photodioda }\end{array}$ \\
Sensor Tekanan & Sensor Loadcell \\
Sensor Temperatur & Sensor NTC, LM35, dan Thermokopel \\
Sensor Proximity & Sensor Proximity Induktif dan kapasitif \\
\hline \multicolumn{2}{c}{ Putra (2017) Jobsheet Praktikum Sensor dan Tranduser } \\
\hline \multicolumn{1}{c}{ Materi Ajar } & \multicolumn{1}{c}{ Materi yang sudah Dikembangkan } \\
\hline Sensor Cahaya & Sensor LDR (Light Dependent Resistor) dan \\
\multicolumn{2}{c}{ Photodioda } \\
Sensor Kelembaban & Sensor HS-1101 \\
Sensor Temperatur & Sensor PTC, NTC, LM35, Thermistor \\
Sensor Gas & Sensor TGS 2601 \\
Sensor tekanan & Sensor strain gauge \\
Sensor Ultrasonik & Sensor HC-SR04
\end{tabular}

\section{4) Preliminary Test}

Setelah produk pengembangan selesai dibuat, maka langkah selanjutnya adalah dengan menguji valid atau tidaknya produk yang dikembangkan. Melakukan validasi merupakan cara mengumpulkan data atau informasi dari para ahli dibidangnya (validator) untuk menentukan valid atau tidak valid terhadap produk buku ajar yang dikembangkan. Tujuan validasi adalah untuk mengetahui tingkat kelayakan buku ajar yang dikembangkan sebelum 


\section{TEKNO Jurnal Teknologi Elektro dan Kejuruan}

http://journal2.um.ac.id/index.php/tekno | ISSN 1693-8739 / 2686-4657

buku ajar digunakan secara umum. Uji validitas dilakukan kepada 3 jenis validator (Dosen Jurusan Teknik Elektro Universitas Negeri Malang). Subjek validasi pada penelitian ini terdiri dari Dosen ahli I, Dosen ahli II, dan Dosen pengampu matakuliah sensor dan tranduser.

5) Main Revision Product

Produk yang telah divalidasi oleh kedua ahli, tahap selanjutnya adalah melakukan revisi terhadap produk. Revisi produk dilakukan apabila dalam format penulisan maupun standar isi banyak kelemahan dan kekurangan sehingga revisi produk bersumber pada hasil angket dari ahli validator yang dikumpulkan. Berbagai tanggapan, kritik, dan saran dari para ahli di analisa. Dari hasil analisa kemudian peneliti melakukan revisi dan memperbaiki produk yang dikembangkan.

6) Main Field Testing

Langkah berikutnya adalah main field testing. Uji coba lapangan diperlukan untuk menilai kelayakan produk atau buku ajar sensor tranduser berbasis problem solving yang akan dikembangkan. Subjek uji coba adalah mahasiswa S1 Pendidikan Teknik Elektro angkatan 2016 yang sudah menempuh matakuliah sensor dan tranduser dengan jumlah 87 mahasiswa dari tiga offering. Tahap main field testing merupakan tahap untuk menentukan suatu bahan ajar layak digunakan atau tidak.

\section{7) Operational Product Revision}

Operational product revision adalah tahap penyempurnaan akhir berdasarkan sanggahan, kritik dan saran yang didapatkan dari subjek uji coba pada tahap main field testing. Apabila hasil analisis angket menyatakan bahwa buku ajar sensor dan tranduser berbasis problem solving telah efektif dan layak untuk digunakan, maka revisi tidak perlu dilaksanakan.

Jenis data yang terdapat dalam penelitian pengembangan ini merupakan data kualitatif dan kuantitatif. Data kualitatif berupa tanggapan yang diberikan oleh validator berupa kritik maupun saran tentang buku ajar yang dikembangkan. Sedangkan data kuantitatif berupa penilaian terhadap buku ajar berupa skor 1 sampai 4 . Data kuantitatif merupakan penilaian terhadap buku ajar cetak oleh ahli dan mahasiswa yang dinyatakan dalam skor penilaian skala likert dimana mengunakan angka 1 sampai 4 . Data ini memberikan gambaran tentang kelayakan suatu produk melalui tanggapan berupa kritik dan saran dari ahli 1, ahli 2, dan mahasiswa dalam penyempurnaan produk yang dikembangkan. Sampel yang diambil dalam penelitian ini adalah mahasiswa S1 Pendidikan Teknik Elektro angkatan 2016 yang telah menempuh matakuliah sensor dan tranduser.

Instrumen pengumpulan data dalam pengembangan ini menggunakan angket yang ditentukan melalui skala likert. Indikator skala likert dapat ditunjukkan melalui Tabel 3. Teknik 


\section{TEKNO Jumal Teknologi Elekrio dan Kejurron}

http://journal2.um.ac.id/index.php/tekno | ISSN 1693-8739 / 2686-4657

analisis data dilakukan setelah semua data terkumpul. Proses analisis data dilakukan dengan cara perhitungan presentase hasil penyebaran angket yang telah disusun sebelumnya.

Tabel 3. Tingkat Penilaian

\begin{tabular}{|c|c|c|}
\hline No & Deskripsi & Skor \\
\hline 1 & Sangat baik/Sangat Layak/Sangat menarik/Sangat mudah/Sangat sesuai/Sangat tepat & 4 \\
\hline 2 & Baik/Layak/Tepat/Menarik/Mudah/Sesuai & 3 \\
\hline 3 & Kurang baik/kurang layak/kurang menarik/kurang mudah/kurang sesuai/kurang tepat & 2 \\
\hline 4 & Tidak baik/tidak layak/tidak menarik/tidak mudah/tidak sesuai/tidak tepat & 1 \\
\hline
\end{tabular}

\section{Hasil}

Produk yang dikembangkan pada penelitian pengembangan ini adalah "Buku Ajar Sensor Tranduser untuk Jurusan Teknik Elektro Universitas Negeri Malang". Perancangan produk buku ajar ini dimulai dari mendesain cover, memetakan materi pada setiap bab dan subbab, menyisipkan model pembelajaran problem solving, rangkuman, daftar rujukan dan index. Desain produk yang dibuat adalah hasil dari observasi yang dilakukan sesuai dengan tempat dan sasaran yang digunakan sebagai subjek penelitian pengembangan yang didalamnya mencangkup materi-materi yang diperlukan oleh mahasiswa. Hasil dari desain cover buku ajar Sensor Tranduser dapat ditunjukkan pada Gambar 4.

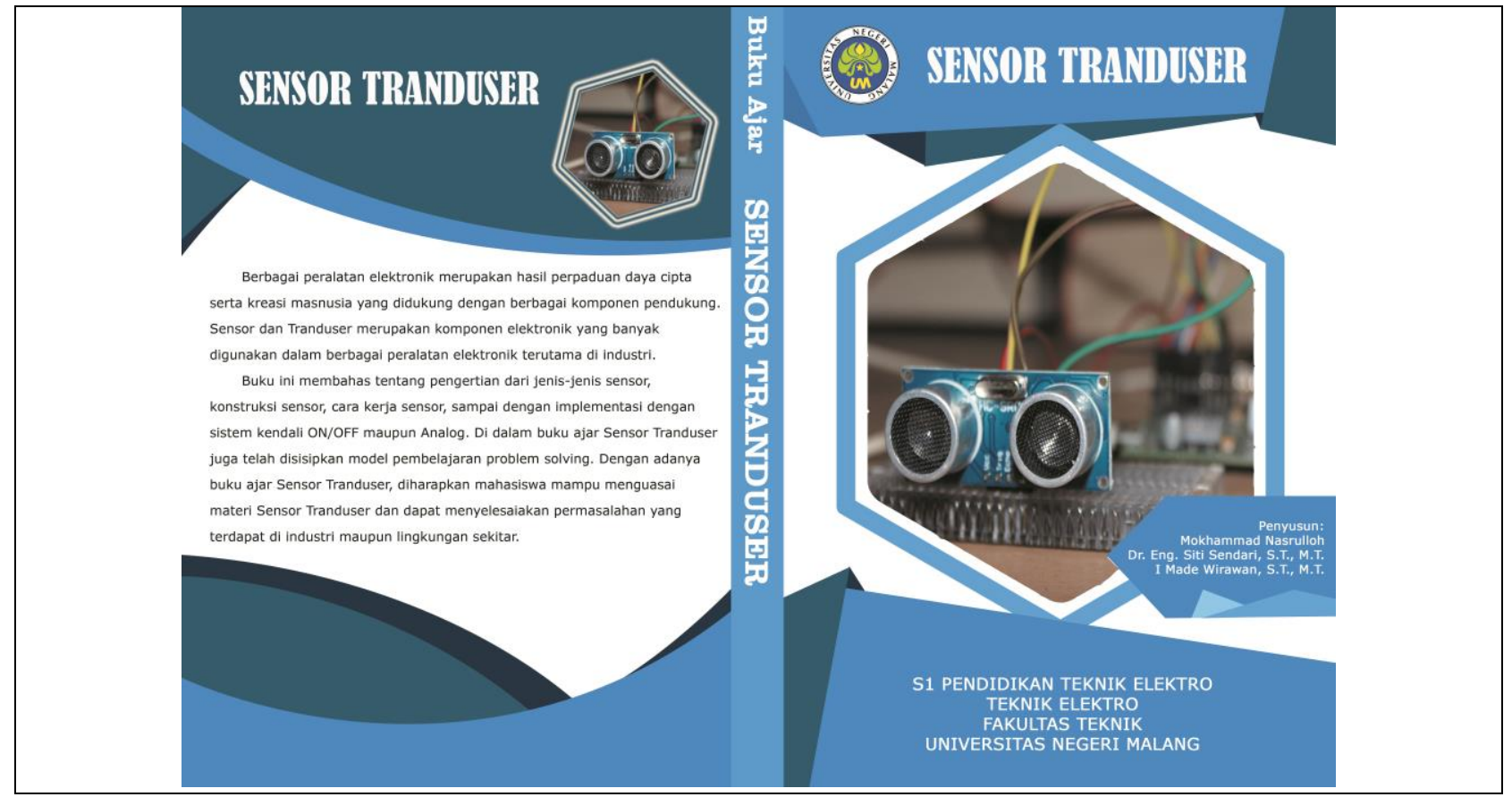

Gambar 4. Halaman Sampul Buku Ajar Sensor Tranduser 


\section{TEKNO Jurnal Teknologi Elektro dan Kejuruan}

http://journal2.um.ac.id/index.php/tekno | ISSN 1693-8739 / 2686-4657

Berdasrkan observasi yang telah dilakukan, produk buku ajar didesain sedemikian rupa sehingga memudahkan mahasiswa belajar didalam kelas. Buku ajar Sensor Tranduser dikembankan sesuai dengan kebutuhan mahasiswa yang ada dijurusan Teknik Eketro Universitas Negeri Malang. Buku ajar ini didesain dengan ukuran A4 $(21 \times 29,7 \mathrm{~cm})$ dengan tebal $80 \mathrm{gsm}$, menggunakan jenis tulisan Verdana, dan didesain berdasarkan katalog S1 Pendidikan Teknik Elektro.

Produk sebelum dibuat, harus divalidasi terlebih dahulu oleh validator yakni ahli. Setelah desain produk (sesuai peta konsep) divalidasi tahap selanjutnya yaitu pemilihan materi-materi yang dibutuhkan, diketik ulang, dan menjadikannya menjadi satu kesatuan.

Produk penelitian pengembangan yang telah dibuat selanjutnya harus divalidasi. Validasi pertama kali dilakukan oleh ahli yang terdiri dari tiga dosen jurusan Teknik Elektro Universitas Negeri Malang. Ketiga dosen tersebut nantinya akan menvalidasi produk yang dikembangkan dari segi media maupun materi. Validasi yang kedua dilakukan oleh mahasiswa S1 Pendidikan Teknik Elektro angkatan 2016 yang telah menempuh matakuliah sensor dan tranduser jurusan Teknik Elektro Universitas Negeri Malang.

1) Penyajian dan Analisis Data Hasil Validator

Hasil dari validasi oleh ketiga validator pada Tabel 4, didapat rata-rata persentase sebesar $89,78 \%$. Sehingga dapat dikatakan produk tersebut masuk dalam kriteria layak dengan revisi kecil. Adapun saran yang diberikan oleh ahli sebagai bentuk penyempurnaan produk buku ajar sebagai berikut: (1) layout cover kurang sesuai; (2) jenis dan ukuran font yang berbeda; (3) konten yang kurang sesuai; (4) tata letak daftar isi; dan (5) kurangnya sumber yang mutakhir. Adapun hasil validasi dari ketiga validator dapat disajikan pada Tabel 4 .

Tabel 4. Hasil Validasi Ahli

\begin{tabular}{clccc}
\hline No & Aspek Penilaian & Tse & Tsh & V\% \\
\hline 1 & Kelayakan Isi & 44.33 & 48 & 92.36 \\
2 & Kelayakan Bahasa & 20.33 & 24 & 84.72 \\
3 & Kelayakan Penyajian & 26 & 28 & 92.86 \\
4 & Kelayakan Kegrafikan & 48 & 52 & 92.31 \\
5 & Kelayakan Unsur & 17.33 & 20 & 86.67 \\
\hline & Jumlah & $\mathbf{1 5 6}$ & $\mathbf{1 7 2}$ & $\mathbf{8 9 . 7 8}$ \\
\hline
\end{tabular}

2) Penyajian dan Analisis Data Hasil Uji Coba Kelompok Kecil tahap berikutnya adalah uji coba kelompok kecil yang dilakukan kepada mahasiswa S1 Pendidikan Teknik Elektro angkatan 2016 sebanyak 12 orang. Hasil dari uji coba kelompok kecil oleh mahasiswa S1 Pendidikan Teknik Elektro angkatan 2016 pada Tabel 5, didapat rata-rata persentase sebesar $89,78 \%$. Sehingga dapat dikatakan produk tersebut masuk dalam kriteria layak dengan revisi kecil. Adapun hasil uji coba kelompok kecil dapat disajikan pada Tabel 5 . 


\section{TEKNO Jumal Teknologi Eektro dan Kejuruon}

http://journal2.um.ac.id/index.php/tekno | ISSN 1693-8739 / 2686-4657

Tabel 5. Hasil Uji Coba Kelompok Kecil

\begin{tabular}{clccc}
\hline No & Aspek Penilaian & Tse & Tsh & V\% \\
\hline 1 & Tampilan & 255 & 288 & 88.54 \\
2 & Materi & 548 & 624 & 87.82 \\
3 & Manfaat & 87 & 96 & 90.63 \\
\hline & Jumlah & 890 & 1008 & 88.29 \\
\hline
\end{tabular}

3) Penyajian dan Analisis Data Hasil Uji Coba Kelompok Besar

tahap berikutnya adalah uji coba kelompok besar yang dilakukan kepada mahasiswa S1 Pendidikan Teknik Elektro angkatan 2016 sebanyak 71 orang. Hasil dari uji coba kelompok besar oleh mahasiswa S1 Pendidikan Teknik Elektro angkatan 2016 pada Tabel 6, didapat rata-rata persentase sebesar 90,56\%. Sehingga dapat dikatakan produk tersebut masuk dalam kriteria layak. Adapun hasil uji coba kelompok besar dapat disajikan pada Tabel 6.

Tabel 6. Hasil Uji Coba Kelompok Besar

\begin{tabular}{clccc}
\hline No & Aspek Penilaian & Tse & Tsh & V\% \\
\hline 1 & Tampilan & 1562 & 1704 & 91.67 \\
2 & Materi & 3300 & 3692 & 89.38 \\
3 & Manfaat & 539 & 568 & 94.89 \\
\hline & Jumlah & 5401 & 5964 & 90.56 \\
\hline
\end{tabular}

Berdasarkan hasil validasi yang telah dilakukan oleh ahli dan responden, maka hasil dari validasi tersebut dapat disajikan dalam bentuk grafik pada Gambar 5.

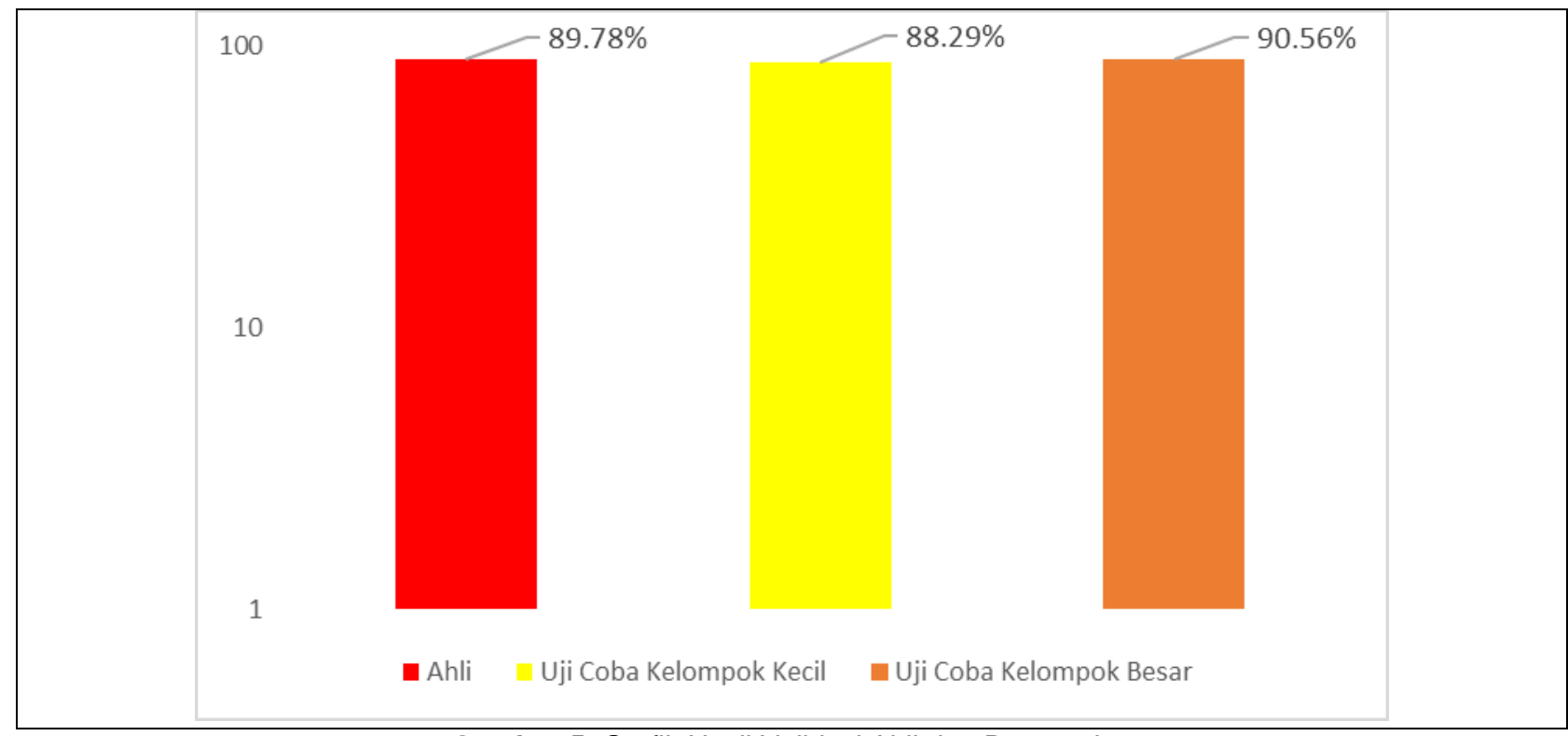

Gambar 5. Grafik Hasil Validasi Ahli dan Responden 


\section{TEKNO Jurnal Teknologi Elektro dan Kejuruan}

http://journal2.um.ac.id/index.php/tekno | ISSN 1693-8739 / 2686-4657

\section{Kesimpulan}

Berdasarkan uraian hasil penelitian, maka dapat dikemukakan kesimpulan sebagai berikut:

- Pengembangan produk diawali dengan research and information collecting, planning, develop preliminary from of product, pada tahap perencanaan dimulai dengan memilih model pengembangan, yaitu model Borg \& Gall. Berdasarkan 3 tahap tersebut maka dapat ditentukan tujuan pembelajaran, materi yang akan dimuat, serta desain pembelajaran yang akan digunakan. Selanjutnya mengembangkan kriteria untuk uji coba produk.

- Dalam tahap pengembangan desain intruksional, buku ajar dikembangkan dengan desain Problem Solving. Model pembelajaran problem solving terdiri dari 5 langkah desain, yaitu (1) Adanya masalah yang jelas, (2) Mencari data dan infromasi, (3) Menetapkan jawaban sementara, (4) Menguji jawaban sementara, (5) Kesimpulan.

- Produk yang dikembangkan telah divalidasi baik secara materi maupun media serta telah diuji coba kelayakannya pada mahasiswa PTE angkatan 2016. Hasil validasi ahli sebesar 89,78 \%. Hasil uji coba kelompok kecil sebesar 88,29\%. Untuk hasil uji coba kelompok besar mencapai 90,56\%. Dari produk yang dikembangkan dapat disimpulkan bahwa produk layak untuk dimanfaatkan dalam pembelajaran matakuliah Sensor dan Tranduser.

\section{Daftar Rujukan}

Ervina, E., Jaya, M. T. BS., dan Pargito, P. 2017. Pengaruh Efektivitas Pengembangan Bahan Ajar dan Minat Belajar Siswa terhadap Prestasi Belajar Matematika Siswa. Jurnal Pedagogi, 6, 6.

Hadis, A dan Nurhayati. 2012. Manajemen Mutu Pedidikan. Bandung: Alfabeta.

Lestari, P. B. dan Hartati, T. W. 2017. Efektifitas Pengembangan Bahan Ajar Mikrobiologi Berbasis Inkuiry dalam Meningkatkan Hasil Belajar Mahasiswa IKIP Budi Utomo Malang. Proceeding Biology Education Conference, 14, 1, 518-521.

Lestari, L. dan Sofyan, D. 2014. Perbandingan Kemampuan Pemecahan Masalah Siswa dalam Matematika Antara yang Mendapat Pembelajaran Matematika Realistik (PMR) dengan Pembelajaran Konvensional. Jurnal Pendidikan Matematika, 3, 2, 95-108.

Prastowo, Andi. 2012. Panduan Kreatif Membuat Bahan Ajar Inovatif. Jogjakarta: Diva Press.

Putra, D. P. 2017. Pengembangan Modul Praktikum LAB PTE-04 Pokok Bahan Sensor dan Tranduser Untuk Mahasiswa Jurusan Teknik Elektro Universitas Negeri Malang. Skripsi. Universitas Negeri Malang.

Putri, A. D. K. dan Imaniyati, N. 2017. Pengembangan Profesi Guru dalam Meningkatkan Kinerja Guru. Jurnal Pendidikan Manajemen Perkantoran, 2, 2, 202-211.

Rusdiyanto, B. 2015. Pengembangan Trainer Sensor Pada Mata Pelaaran Sensor dan Tranduser Kelas XI Jurusan Teknik Elektronika Industri di SMK Negeri Singosari. Skripsi. Universitas Negeri Malang. 


\section{TEKNO Jurnal Teknologi Elektro dan Kejuruan}

http://journal2.um.ac.id/index.php/tekno | ISSN 1693-8739 / 2686-4657

Setiawan, M. A., Dasna, I. W., dan Marfu'ah, S. 2016. Pengaruh Bahan Ajar Multimedia Terhadap Hasil Belajar dan Persepsi Mahasiswa pada Matakuliah Kimia Organik I. Jurnal Pendidikan: Teori, Penelitian, dan Pengembangan, 1, 4, 746-751.

Sugiyono. 2016. Metode Penelitian Kuantitatif Kualitatif dan R\&D. Bandung: Alfabeta. Sunarti dan Rohmawati. 2014. Penilaian dalam Kurikulum 2013. Yogyakarta: Andi Offset.

Widiani, N. 2016. Penerapan Model Pembelajaran Creative Problem Solving untuk Meningkatkan Keaktifan Siswa dalam Pembelajaran PKN. Jurnal Pendidikan Guru Sekolah Dasar, 11, 5, 1062-1073. 